\title{
Death Is Called Engelchen (Smrt' sa volá Engelchen)
}

Author: Ladislav Mňačko

First Published: 1959

Translations: translated into almost 20 languages, among others Russian, Polish, German, French and Spanish.

Film Adaptations: Smrt’sa volá Engelchen (Death Is Called Engelchen), TV film, screenplay Ladislav Mňačko and Daniel Michaeli; film director Ivan Balada, premiered 1960; Smrt si ř́ká Engelchen (Death Is Called Engelchen), screenplay and film directors Ján Kadár and Elmar Klos, premiered the 3rd of May, 1963.

About the Author: Ladislav Mňačko (1919-1994) was a Slovak writer and journalist. He became the most translated Slovak author in the world. His parents were Czechs living in Moravia. He spent his childhood and youth in the town of Martin in Central Slovakia where his father worked as a postmaster. He did not finish his studies at high school and instead got training to work in a drugstore. In 1940, he tried to cross the border between Germany and the Netherlands; he was detained and imprisoned. In 1944 Mňačko escaped from the forced labour camp in the Ruhr region in Germany and took part in the partisan movement in East Moravia. After the war, he was at first a staunch supporter of the Czechoslovak Communist regime and one of its most prominent journalists. He travelled both in Czechoslovakia and abroad and wrote many reports (for instance books about Israel, China and Vietnam). His works of fiction were also based on actual events and real characters. In 1961, Mňačko took part in the Eichmann Trial in Jerusalem (see his book I, Adolf Eichmann). In the 1960s, he became a vocal critic of the Communist regime, for which he was censored. Due to the Warsaw Pact invasion of Czechoslovakia in August 1968, he emigrated first to Israel, later to Austria, where he lived for the next 20 years. His works were forbidden in Czechoslovakia. After the fall of the Communist regime in November 1989, he returned and lived in Slovakia. But subsequent political developments and the growth of nationalism in Slovakia disappointed him. After the dissolution of Czechoslovakia (1992), he moved to Prague.

Further Important Publications: Izrael (Israel, 1949; reportages); Já, Adolf Eichmann (I, Adolf Eichmann, 1961; a report about Eichmann and the Eichmann Trial); Nočný rozhovor (Dialogue in the Night, 1966; novel).

\section{Content and Interpretation}

The novel is divided into ten chapters and set in Moravian Wallachia (Valašsko) in East Moravia in the last months of World War II and first months after it. The author

Ә Open Access. (C) 2021 Jiři Holý, published by De Gruyter. (cc)BY-NC-ND This work is licensed under a Creative Commons Attribution-NonCommercial-NoDerivatives 4.0 License. https://doi.org/10.1515/9783110671056-024 
used the frame narrative composition. The narrator and main character is Voloda, a 24 years old partisan fighting against the Nazis who was seriously injured and after the war must spend four months in the hospital. He has some features which enable to identify him with the author of the novel and the whole novel is based on real events. The story (actual time of the narration) is set around Voloda's stay in the hospital, his dialogues with the doctor, his visitors and mainly the nurse Eliška with whom he falls in love. However, the main storyline takes place in the past, through flashbacks of Voloda's memories. There are partisan fights with Germans, Voloda's fatal love for the young woman Martha (Marta) and the village of Ploština in the mountains that is a base for the partisans. However the partisan unit is infiltrated by traitors and Ploština is set ablaze by the Germans for helping partisans; the village men are burned alive. On that day, the partisans are absent and can not defend the village. Voloda and his co-fighters are stricken with deep remorse while innocent people are dying because of them. At the end of the novel, the healed Volod'a leaves the hospital to find and punish the SS officer Engelchen (Engelchen means a little angel in German) who is responsible for the massacre in Ploština.

The Jewish topic is connected with the character of Martha. She is a beautiful and mysterious woman. She works for the Gestapo as a secretary and sleeps with Nazi officers to gain information that she then provides to the partisans. Voloda gets to know her in the partisan base of Ploština and is sent to accompany her to the town Zlin. They spend the night together there and become lovers. The Nazis humiliate Martha; one general scars her back with a riding crop. The partisans take revenge, by assaulting the general and his unit. Martha kills the general herself and the partisans also kill other high ranking officers. Nevertheless, this attack sets the Germans against them and the villagers. Only gradually is it revealed to Voloda, that Martha is a Jewess and has a double identity. An indication of it may be that she quotes the Book of Ruth while they are making love for the first time. After the war, Martha is traumatised by the events that she has experienced and commits suicide.

\footnotetext{
Martha: "I had to go the way of all Jews. The way to Auschwitz..."

[...]

I said to her, "Martha, you can go to Auschwitz, to tell millions of the Jews, you are a Jewess, you slept with the Germans, but only for the few of the Jews was it as hard as it was for you..." (Mňačko, 2016, p. 37).
}

The Holocaust is implied in a scene where the partisans capture a German unit. Soldiers are disarmed and released but the officer should be executed. Voloda is supposed to shoot him dead. The German officer is a calm, distinguished man, who constantly carries a book under his arm. He tells Voloda that he has never killed anyone in the war while being a part of a technical rear guard unit. The officer gives him his book which he is reading, Galsworthy's The Forsyte Saga, is actually a forbidden book in Germany. When Voloda opens the novel, he finds the name of its former owner, Armin Weiss, a Jew. In a fit of rage, Voloda shoots the German officer. 
The novel uses the same devices as thrillers. The author keeps readers in tension, dramatic events are disclosed step by step in flashbacks. The character of Martha includes the features of a femme fatale, while the nurse Eliška is calm, patient and devoted. On the one hand, the story deheroises the partisan movement in Czechoslovakia authentically depicting the fight against the Nazis including the topic of the Jews what did not appear in the literature of the 1950s in Czechoslovakia. On the other hand, in several ways the novel is still schematic (the role of the Red Army and Communist Party as well as the criticism against the First Czechoslovak Republic).

\section{Real Background of the Story and Film Adaptation}

The novel was firstly published in Czech in the daily Mladá fronta (1959). Then it was edited as a book in Slovak in the same year. It received a great acclaim and was translated in many languages.

Ploština was a small settlement in Moravian Wallachia. On April 19, 1945, at the end of World War II, it was burned and its people were massacred by the Nazis in response to their support of the partisan movement. It was the result of the denunciation caused by agents of the Gestapo who wormed themselves into the Partisan Brigade of Jan Žižka of which Ladislav Mňačko was also a member. Nevertheless, Mňačko didn't know and describe the whole background of the events. Only after 1989 was possible to give true testimony about these events (Novák, 2003; Pospíšil, 2003).

Mňačko's interest in Jewish topics was undoubtedly peaked through his first wife Hedwiga, a Jewess, whom he met in Germany during the war. He presented a positive image of the Jewish nation in his reportage book Israel (1949). Later, as an eyewitness, Mňačko described the Eichmann Trial in Jerusalem, and in 1967 he went to Israel protesting against the official statement of the Soviet Bloc regarding the Six-Day Arab-Israeli War.

The novel Death Is Called Engelchen was first filmed in 1960 by the Slovak director Ivan Balad’a as a TV film. The second adaptation, made in 1963 by directors Ján Kadár and Elmar Klos in Czech, became world-renowned. The filmmakers preserved the main line of the plot. Like in the novel, various narrative times are interweaved, the present is followed by various events from different points in the past. Several names, characters and situations were changed. The partisan and narrator was named Pavel Kubec, the nurse in the hospital is Elizabeth (Alžběta), a nun, and her love relationship to Pavel was downplayed. At the beginning of the film, Martha seems to be dead having committed suicide immediately after the liberation of Zlin. Astonishingly, she later visits Pavel in the hospital to tell him goodbye. The village which is burned by the Nazis is called Paseky, a fictitious place, not the authentic Ploština. The book that is carried by the "good" German officer, originally owned by a Jew, is Thomas Mann's novel Buddenbrooks. Earlier, Pavel had found this work in Martha's library. Generally, the film is more compact and impressive. 


\section{Cited Work}

Mňačko, L. (2016). Smrt'sa volá Engelchen. 9th edition. Bratislava: Vydavatel'stvo Európa.

\section{Further References}

Auer, S. L. (1989). Vom sozialistischen Realismus zu Kritizismus und Satire. Ladislav Mňačkos Romanwerk. Bern: Peter Lang. Drug, Š. (1960). Chlapská kniha. Kultúrny život, 15(2), p. 4. Klátik, Z. (1960). Smrt’ sa volá Engelchen. Slovenské pohlady, 76(2), p. 232. Kusý, I. (1961). Slovenská próza v rokoch 1958-1960. In: K problematike slovenskej prózy. Bratislava: Slovenská akadémia vied, p. 279. Leikert, J. (2007). Taký bol Ladislav Mňačko: v historickom kontexte do roku 1968. Brno: Onufrius. Matuška, A. (1960). Ešte Smrt'sa volá Engelchen. Kultúrny život, 15(7), p. 4. Novák, J. (2003). Ploština - krvavá paseka. TV documentary. Available at: https://www.youtube.com/watch?v=61uGiFCPAmA [Accessed: 11.05.2019] Patera, L. (1995). Paradoxy „opožděného reportéra“. Slovenské rozhlady, 2(3), pp. 204-206. Pospíšil, J. (2003). Hyeny v akci. Vizovice: Lípa. Sladovníková, Š. (2018). The Holocaust in Czechoslovak and Czech Feature Film. Stuttgart: ibidem, pp. 37-39. zp (Prušková, Z.). (2006). Mňačko, Ladislav: Smrt’ sa volá Engelchen. In: R. Chmel et al., Slovník diel slovenskej literatúry 20. storočia. Bratislava: Kalligram, pp. 275-277.

$\mathrm{JH}$ 